\title{
Physical and Biochemical Characterization of Sweet Corn Ears of Four Varieties Grown in Senegal
}

\author{
Nafissatou Diop Ndiaye, PhD \\ Institut de Technologie Alimentaire, \\ Route des Pères Maristes, Dakar - Hann, Sénégal \\ Mady Cisse, PhD \\ Université Cheikh Anta Diop de Dakar (UCAD)-Ecole Supérieure \\ Polytechnique (ESP). Avenue Cheikh Anta Diop, Dakar \\ Fatou Diop Mbacke \\ Institut Sénégalais de Recherche Agricole (ISRA)-Centre pour le \\ Développement de l'Horticulture (CDH)

\section{Abou Diop} \\ Centre de Formation Professionnelle en Horticulture (CFPH). Route de \\ Cambérène, $\mathrm{PA}$ \\ Saliou Ndiaye, PhD
}

Ecole Nationale Supérieure Agronomique-Université de Thiès

Thomas Thompson, PhD

Virginia Tech College of Agriculture and Life sciences

Doi: 10.19044/esj.2017.v13n33p232 URL:http://dx.doi.org/10.19044/esj.2017.v13n33p232

\section{Abstract}

Sweet corn is an underutilized crop for human consumption in Senegal. In this study, physical and biochemical characterization were performed on four sweet corn ear varieties grown at three different fertilization rate of $15 \mathrm{~N}-15-\mathrm{P}-15 \mathrm{~K}$. Treatment F1 was 40 tons/Ha horse-dung $+200 \mathrm{~kg} / \mathrm{Ha}$ of $15 \mathrm{~N}-15 \mathrm{P}-15 \mathrm{~K}$, treatment $\mathrm{F} 2$ was 30 tons/Ha horse-dung + $150 \mathrm{~kg} / \mathrm{Ha}$ of $15 \mathrm{~N}-15 \mathrm{P}-15 \mathrm{~K}$ ) and treatment $\mathrm{F} 3$ was 50 tons/Ha horse-dung + $250 \mathrm{~kg} / \mathrm{Ha}$ of $15 \mathrm{~N}-15 \mathrm{P}-15 \mathrm{~K}$. Results showed that Yosemite cultivar gave the highest number of kernels/ear (672.3), followed respectively by Legacy (642), Excellis Garrison (585.6) and Infinity (573). Furthermore, treatments using fertilizer 3 (F3: 50 tons/Ha horse-dung $+250 \mathrm{~kg} / \mathrm{Ha}$ of $15 \mathrm{~N}-15 \mathrm{P}-15 \mathrm{~K}$ ) led to the highest number of kernels/ear in all cultivars used. Interestingly, Legacy cultivar gave more reducing sugars $\left(5.1 \pm 0.8\right.$ g. $\left.100 \mathrm{~g}^{-1}\right)$ with treatment $\mathrm{F} 1$; treatment $\mathrm{F} 3$ provided less reducing sugars $\left(2.1 \pm 0.6 \mathrm{~g} .100 \mathrm{~g}^{-1}\right)$ and more starch $\left(14.4 \pm 0.5 \mathrm{~g} .100 \mathrm{~g}^{-1}\right)$. Overall, physical and biochemical characteristics were influenced to at least some extent by fertilization 
treatments related to the cultivar used. Yosemite and Legacy cultivars would be more suitable for canned sweet corn production in the conditions studied. Sangalkam seems to be more suitable for sweet corn production.

Keywords: Zea mays saccharata, Shrunken-2, Number of kernels/ear, Sugars

\section{Introduction}

Sweet corn is an underutilized crop in Senegal, but increasing its production and cultivation could have major benefits for the economy. Sweet corn is primarily used as a fresh market product or it is preserved through canning or deep freezing processing (Alan et al., 2014). Many studies have already been conducted on sweet corn (Hale et al., 2005; Mullins et al., 1999; Simonne et al., 1999; Azanza et al., 1996; Wong et al., 1994). In Senegal, sweet corn was introduced in 2004 (Sy Diouf, 2013) and contributed significantly to the diversification of exported horticultural crop varieties. Sweet corn was identified as a crop with high potential in Senegal and as one of the most important niche markets of the agricultural sector (Sow et Lagnane, 2011). In Senegal, sweet corn is essentially produced for exportation in the Northern area (Senegalese valley rift) to Europe where it is marketed. Senegalese exportation (with $7 \%$ of post-harvest losses nationally) was respectively 8,546; 10,124 and 12,253 metrics tons in 2013, 2014 and 2015 (DHORT, 2016). The sweet corn farming industry has been challenged with two major problems. First, five big private foreign companies occupy the industry and local small farmers have not had access to farming opportunities. Second, Senegal imports cans of sweet corn for national market. Specific data on imported sweet corn cans is not available. However, the Senegalese Agency for Foreign Commerce provided between 28.7 to 305 tons in the period of 2012 to 2015 (SAFC, 2016).

Sweet corn is source of fibers (2.3 to $\left.4.25 \mathrm{~g} .100 \mathrm{~g}^{-1}\right)$ and vitamin B9 (23 to $88 \mu \mathrm{g} .100 \mathrm{~g}^{-1}$ ); it has a moisture content of $70 \%$ and a total carbohydrate content of $23 \%$, with $27 \%$ of the total carbohydrate content comprised by starch (Aprifel, 2012; Lertrat and Pulam, 2007; Szymanek et al., 2006; Péron, 2006). Nevertheless, the chemical composition of sweet corn kernels is related to weather conditions, ripeness and storage methods (Salunkhe and Kadam, 1998). According to Szymanek (2012), optimum kernel moisture ranges from 70 to $76 \%$ for whole kernels used for canning or freezing. Sweet corn quality (fresh or processed) is determined by the combination of aroma, texture and flavor. In this regard, sugar and starch contents strongly affect taste and sweetness, which is important for flavor (Alan et al., 2014; Szymanek, 2012; Lertrat and Pulam, 2007; Azanza et al., 1994; Wong, 1994; Flora and Wiley, 1974). In other words, sugar content 
and its conversion into starch is related to moisture content, which has a drastic impact on taste (Szymanek, 2012; Wong, 1994). Three types of sweet corn cultivars exist on the basis of their sugar contents: sugary ( $s u$, normal sweet cultivars with 4 to $6 \%$ sugar contents), sugary enhancement (se, cultivars with 6 to $8 \%$ sugar content) and shrunken-2 (sh2, 8 to $12 \%$ sugar content, considered very sweet) (Warzecha, 2003). After harvesting, sugary cultivars rapidly lose their kernel quality due to moisture loss and conversion of sugar into starch. Compared to shrunken cultivars, a slow conversion of sugar into starch is observed (Azanza et al., 1996, Carey et al., 1982, 1984).

In Senegal, there is a lack of knowledge about local sweet corn varieties despite the work done by Diallo et al., (2016), who studied the response of five sweet corn cultivars (Prime plus, Shy 1036, Colombus, GSS and JKMH-45) to different fertilization treatments experimented in SaintLouis (Senegal). Nevertheless, this study was focused only on agronomic parameters including: height 30 days after sowing, 50\% flowering rate, height of higher ear, 60 days silk quality after sowing, number of ears/plant and number of kernels/ear. This current research was carried out to determine physical and biochemical characteristics of four shrunken-2 sweet corn cultivars grown with three different fertilization treatments. Results were intended to be used as guidelines for future production of sweet corn in the Senegalese canning industry. We chose shrunken-2 (sh2) phenotype because its kernels produce more sugars at harvest maturity (Creech, 1965). Furthermore, sh2 phenotype can keep its high contents of sugar for a long postharvest period (Garwood et al., 1976). In addition, consumers prefer its taste in comparison with su or se phenotypes (Evensen and Boyer, 1986; Showalter and Miller, 1962).

\section{Materials and methods \\ Sweet corn production}

Four sh-2 yellow sweet corn cultivars: Excellis Garrison F1 (Syngenta seeds), Legacy (Starke Ayres), Infinity (Harris Moran seed company) and Yosemite (Starke Ayres) were studied in 2013 and 2014. Fields of the Senegalese Institution for Agricultural Research were used as experimental stations. They were located at Sangalkam $\left(14^{\circ} 46^{\prime} 52^{\circ} \mathrm{N} ; 17^{\circ}\right.$ $\left.13^{\prime} 40^{\prime} \mathrm{W} ; 7 \mathrm{~m}\right)$ and Ndiol $\left(16^{\circ} 8^{\prime} 22^{\prime}{ }^{\prime} \mathrm{N} ; 16^{\circ} 19^{\prime} 5^{\prime}, \mathrm{W} ; 7 \mathrm{~m}\right)$, respectively, in Niayes and Senegalese Rift Valley Region. The soil in Sangalkam station was clayey, rich and fertile with high demand for water (Delsoin, 2014). Meanwhile in Ndiol, the soil was sandy, dry and poor (Diallo et al., 2016). A Fisher's randomized complete block design (RCBD) with four repetitions was used for each cultivar. Each block had 15 plots, and each plot was $27 \mathrm{~m}^{2}$ (9x3) and had 5 lines separated by an alley of $1 \mathrm{~m}$ width. This allowed for the elimination of edges effects. Seeds were sown in Ndiol on November 29, 
2013 and in Sangalkam on January 24, 2014. A planting density of 50, 000 plants/ha was applied with a spacing of $75 \mathrm{~cm} \times 25 \mathrm{~cm}$. Three different fertilization rates of $15 \mathrm{~N}-15 \mathrm{P}-15 \mathrm{~K}$ available in the market were used in combination with horse-dung. Treatment F1 was 40 tons/Ha horse-dung + $200 \mathrm{~kg} / \mathrm{Ha}$ of $15 \mathrm{~N}-15 \mathrm{P}-15 \mathrm{~K}$, treatment $\mathrm{F} 2$ was 30 tons/Ha horse-dung +150 $\mathrm{kg} / \mathrm{Ha}$ of $15 \mathrm{~N}-15 \mathrm{P}-15 \mathrm{~K}$ ) and treatment $\mathrm{F} 3$ was 50 tons/Ha horse-dung +250 $\mathrm{kg} / \mathrm{Ha}$ of $15 \mathrm{~N}-15 \mathrm{P}-15 \mathrm{~K}$. Table 1 shows an estimate of the total amount of $\mathrm{N}$, $\mathrm{P}, \mathrm{K}$ resulting from the fertilizer used and horse dung application. Sprinkling irrigation was used every two days. Ears were harvested after 101 days at maturity stage and brought to the laboratory for analysis.

Table 1: Available amounts of N, P, K resulted from horse dung and fertilizer application for each treatments

\begin{tabular}{|c|c|c|c|c|c|c|c|c|c|}
\hline \multirow[b]{3}{*}{ Treatments applied } & \multicolumn{9}{|c|}{ Available Amounts } \\
\hline & \multicolumn{3}{|c|}{$\mathrm{N}(\mathrm{kg} / \mathrm{Ha})$} & \multicolumn{3}{|c|}{$\mathrm{P}(\mathrm{kg} / \mathrm{Ha})$} & \multicolumn{3}{|c|}{$\mathrm{K}(\mathrm{kg} / \mathrm{Ha})$} \\
\hline & $\begin{array}{c}\text { Hors } \\
\mathrm{e} \\
\text { dung }\end{array}$ & $\begin{array}{c}\text { Fert } \\
\text { ilize } \\
r\end{array}$ & $\begin{array}{l}\mathrm{T} \\
\text { ot } \\
\mathrm{al}\end{array}$ & $\begin{array}{c}\text { Hors } \\
\mathrm{e} \\
\text { dung }\end{array}$ & $\begin{array}{c}\text { Fert } \\
\text { ilize } \\
r\end{array}$ & $\begin{array}{c}\mathrm{T} \\
\text { ot } \\
\mathrm{al}\end{array}$ & $\begin{array}{c}\text { Hors } \\
\mathrm{e} \\
\text { dung }\end{array}$ & $\begin{array}{c}\text { Fert } \\
\text { ilize } \\
r\end{array}$ & $\begin{array}{l}\mathrm{T} \\
\text { ot } \\
\text { al }\end{array}$ \\
\hline $\begin{array}{l}\text { Treatment F1 = } 40 \text { tons } / \mathrm{Ha} \text { fumier de } \\
\text { cheval }+200 \mathrm{~kg} / \mathrm{Ha} \text { of } 15 \mathrm{~N}-15 \mathrm{P}-15 \mathrm{~K}\end{array}$ & 200 & 30 & $\begin{array}{c}23 \\
0 \\
\end{array}$ & 120 & 30 & $\begin{array}{c}15 \\
0 \\
\end{array}$ & 280 & 30 & $\begin{array}{c}31 \\
0\end{array}$ \\
\hline $\begin{array}{l}\text { Treatment F2 }=30 \text { tons } / \mathrm{Ha} \text { fumier de } \\
\text { cheval }+150 \mathrm{~kg} / \mathrm{Ha} \text { of } 15 \mathrm{~N}-15 \mathrm{P}-15 \mathrm{~K}\end{array}$ & 150 & 22.5 & $\begin{array}{c}17 \\
3\end{array}$ & 90 & 22.5 & $\begin{array}{c}11 \\
3\end{array}$ & 210 & 22.5 & $\begin{array}{c}23 \\
3\end{array}$ \\
\hline $\begin{array}{l}\text { Treatment F3 }=50 \text { tons } / \mathrm{Ha} \text { fumier de } \\
\text { cheval }+250 \mathrm{~kg} / \mathrm{Ha} \text { of } 15 \mathrm{~N}-15 \mathrm{~N}-15 \mathrm{~N}\end{array}$ & 250 & 37.5 & $\begin{array}{c}28 \\
8\end{array}$ & 150 & 37.5 & $\begin{array}{c}18 \\
8\end{array}$ & 350 & 37.5 & $\begin{array}{c}38 \\
8\end{array}$ \\
\hline
\end{tabular}

\section{Determination of physical and biochemical characteristics of ears}

Physical characteristics were recorded on fresh ears of corn after removing covers leaves according to Szymanek et al., (2006). Records were focused on ear weight, ear length, ear diameter, number of kernels in row, number of rows and number of kernels per ear. Twenty ears were analyzed separately from each combination of variety and treatment. Biochemical analyses were conducted for water content, starch and total and reducing sugars using standards methods (AOAC, 2007; AOAC, 1990).

\section{Statistical analysis}

Significant differences $(\mathrm{p}<0.05)$ of the various analyses were determined using SPSS software (version 20.0) using two ways Anova. Newman-Keuls test was used to detect differences.

\section{Results and discussion}

\section{Physical characteristics of sweet corn ears grown at Sangalkam}

Results for physical properties of ears from the four studied sweet corn cultivars are presented in Table 2. For Excellis Garrison cultivar, physical properties were not significantly affected by fertilization treatment rate. Weights of ears without leaves ranged from 210 to $228 \mathrm{~g} .100 \mathrm{~g}^{-1}$ fresh 
matters with $18 \mathrm{~cm}$ length and $47 \mathrm{~mm}$ diameter. The number of kernels/row and the number of rows/ear were respectively around 35 and 16 . The number of kernels/ear was respectively 573, 547 and 586 for F1, F2 and F3 fertilizer treatments (Table 2). These data were closed to those described on the technical variety sheet from the supplier, which indicated $20 \mathrm{~cm}$ length, 50 $\mathrm{mm}$ diameter for a number of rows/ear of 16 (Syngenta, 2013). Ear length was closed to those from Challenger cultivar grown in Tennessee (Mullins et al., 1999).

Table 2: Physical characteristics of sweet corn ears grown at Sangalkam

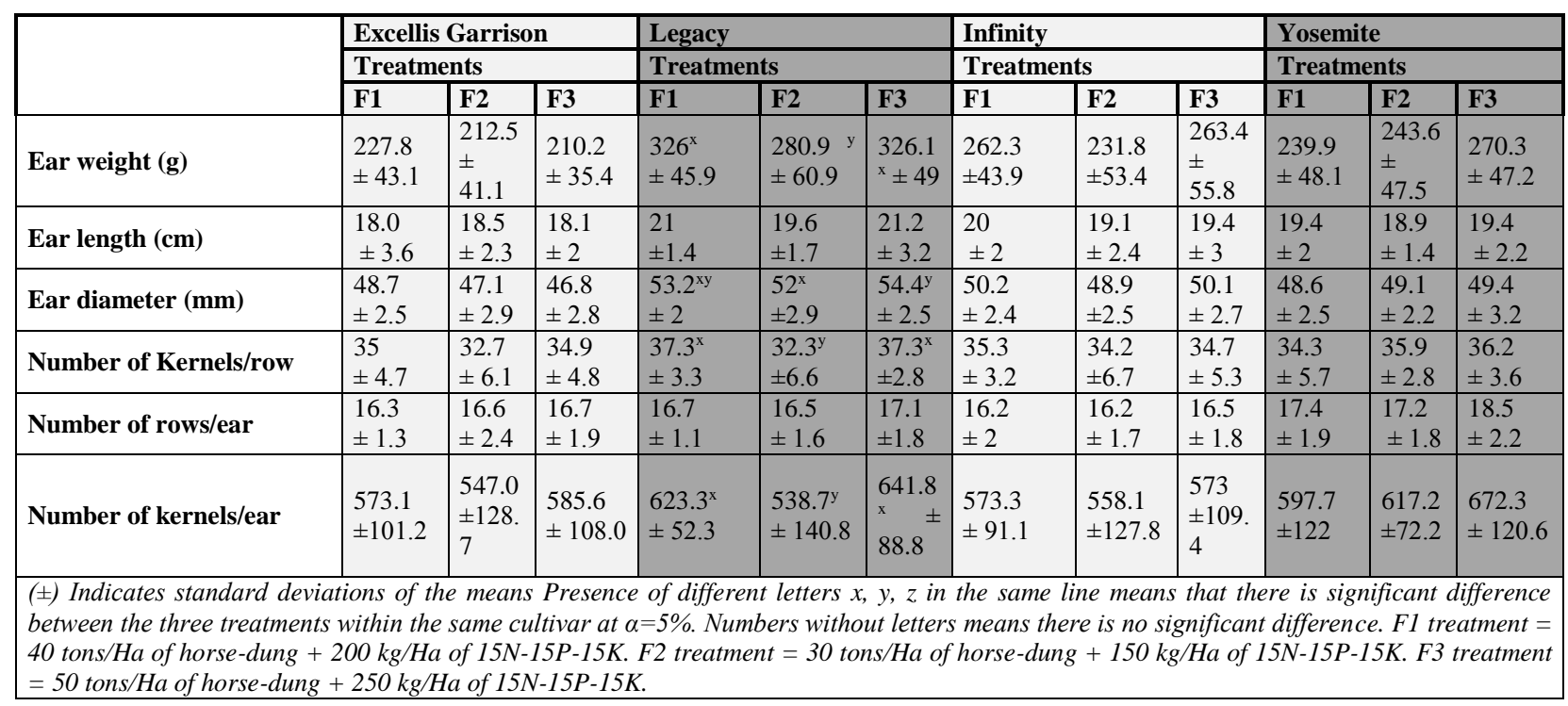

Data recorded for Legacy cultivar showed significantly difference only in ear weight, ear diameter, number of kernels/row and number of kernels/ear. Highest values were obtained in F3 and F1 treatments. Ear diameters of F1 and F3 treatments were slightly higher compared to F2. Ear lengths of these two treatments were slightly higher than those indicated in the technical cultivar sheet (Starke Ayres, 2013a). Differences could be from variations in areas and conditions of cultivation.

For Infinity cultivar, the three fertilizer treatments did not have a significant effect on ear weight, ear length, ear diameter, number of kernels/row, number of rows/ear and number of kernels/ear. Lowest values were obtained with treatment F2 in most cases. Ear lengths were slightly highest to those indicated on the technical sheet of Infinity cultivar mentioning 16-18 cm of length (Stark Ayres, 2013b). Treatments (F1, F2 and F3) did not have a significant impact on all physical parameters for Yosemite cultivar. However, ears obtained with treatment F3 represented the highest number of kernels/ear with an average of 672. Average ear length of Yosemite cultivar in the technical data sheet was around $20.5 \mathrm{~cm}$ with a 
number of rows between 16 to 18 (Harris Moran, 2013). Even if many studies were done on sweet corn cultivars, only one reference was found on sweet corn cultivation in Senegal. Diallo et al., (2016) have worked in the same fertilization conditions, but different varieties and cultivation area were used. Considering the number of kernels/ear as the most important physical parameter for production of canning sweet corn, Yosemite and Legacy cultivars were indicated as best using our studied conditions. Furthermore, sweet corn cultivars used in this study were more efficient than Prime plus, Shy 1036, Colombus, GSS and JKMH-45 tried by Diallo et al., (2016) with the same F1, F2 and F3 fertilization treatments. Diallo et al., (2016) reported that the number of kernels/ear was between 304 and 433. With regard to the recommended amount of nitrogen $(\mathrm{N})$ involved in the fertilization of sweet corn, the application rate was different during the development stage of the plant. In Tennessee for example, the rate of $\mathrm{N}$ was $101 \mathrm{~kg} / \mathrm{Ha}$ at planting and $34 \mathrm{~kg} / \mathrm{Ha}$ when plant height reached between 30.5 and $45.7 \mathrm{~cm}$ (Mullins et al., 1999). In our study, the rates of $\mathrm{N}$ were 230,173 and $288 \mathrm{~kg} / \mathrm{Ha}$, respectively, for treatments F1, F2 and F3.

\section{Physical characteristics of sweet corn ears grown at Ndiol}

Table 3 presents data recorded from ears collected at Ndiol. Excellis Garrisson cultivar showed significant difference in ear weights for F1 and F2 fertilizer treatments with the highest value for F2 treatment $(177.4 \mathrm{~g})$. In Table 3, average ear length was $14 \mathrm{~cm}$ with an average diameter of $45.5 \mathrm{~cm}$. Average number of kernels/ear was 355. Ear characteristics of Legacy and Infinity cultivars were not influenced by fertilization treatments. For Yosemite cultivar, significant differences were recorded for ear weights and diameters, with highest values obtained with F2 treatment. Number of kernels/ear was higher in the Infinity cultivar when F2 treatment was applied. Results from the two stations used in this study, showed that Sangalkam area was more suitable for sweet corn production. For all sweet corn cultivars tested, ear characteristics obtained from Sangalkam were higher. Regarding sweet corn processing, the number of kernels/ear represents a key physical parameter for selecting suitable varieties. Yosemite and Infinity cultivars were selected as more suitable, according to results in Sangalkam (with F3 treatment) and Ndiol (with F2 treatment), for canning processing.

Table 3: Physical characteristics of sweet corn ears grown at Ndiol

\begin{tabular}{|c|c|c|c|c|c|c|c|c|c|c|c|c|}
\hline & \multirow{2}{*}{\multicolumn{3}{|c|}{$\begin{array}{c}\text { Excellis Garrison } \\
\text { Treatments }\end{array}$}} & \multirow{2}{*}{\multicolumn{3}{|c|}{$\begin{array}{l}\text { Legacy } \\
\text { Treatments }\end{array}$}} & \multirow{2}{*}{\multicolumn{3}{|c|}{$\begin{array}{c}\text { Infinity } \\
\text { Treatments } \\
\end{array}$}} & \multirow{2}{*}{\multicolumn{3}{|c|}{$\begin{array}{c}\text { Yosemite } \\
\text { Treatments }\end{array}$}} \\
\hline & & & & & & & & & & & & \\
\hline & F1 & F2 & F3 & F1 & F2 & F3 & F1 & F2 & F3 & F1 & F2 & F3 \\
\hline Ear weight (g) & $\begin{array}{l}128.4^{\mathrm{a}} \\
\pm 47.2 \\
\end{array}$ & $\begin{array}{l}177.4^{\mathrm{b}} \\
\pm 48.5\end{array}$ & $\begin{array}{l}153.6^{\mathrm{ab}} \\
\pm 37.1\end{array}$ & $\begin{array}{r}179.1 \\
\pm 47.1 \\
\end{array}$ & $\begin{array}{l}139.1 \\
\pm 42.4 \\
\end{array}$ & $\begin{array}{r}185.4 \\
\pm 61.6 \\
\end{array}$ & $\begin{array}{r}164.1 \\
\pm 45.8 \\
\end{array}$ & $\begin{array}{r}187.4 \\
\pm 42.4 \\
\end{array}$ & $\begin{array}{r}180.2 \\
\pm 35.4 \\
\end{array}$ & $\begin{array}{l}174.3^{\mathrm{a}} \\
\pm 56.2 \\
\end{array}$ & $\begin{array}{l}232.8^{\mathrm{b}} \\
\pm 60.5 \\
\end{array}$ & $\begin{array}{l}190.1^{\mathrm{ab}} \\
\pm 55.2\end{array}$ \\
\hline Ear length $(\mathrm{cm})$ & $\begin{array}{l}13.6 \\
\pm 2.2\end{array}$ & $\begin{array}{rr}14.7 & \pm \\
2 & \end{array}$ & $\begin{array}{l}14.1 \\
\pm 2.7\end{array}$ & $\begin{array}{r}14.9 \\
\pm 2.3\end{array}$ & $\begin{array}{l}13.4 \\
\pm 1.6\end{array}$ & $\begin{array}{r}15.2 \\
\pm 2.9\end{array}$ & $\begin{array}{r}14.4 \\
\pm 1.8\end{array}$ & $\begin{array}{r}14.3 \\
\pm 1.3\end{array}$ & $\begin{array}{c}17 \\
\pm 8.2\end{array}$ & $\begin{array}{l}15.1 \\
\pm 2.3\end{array}$ & $\begin{array}{r}16.3 \\
\pm 2.3\end{array}$ & $\begin{array}{r}14.6 \\
\pm 2.5\end{array}$ \\
\hline
\end{tabular}




\begin{tabular}{|c|c|c|c|c|c|c|c|c|c|c|c|c|}
\hline Ear diameter $(\mathbf{m m})$ & $\begin{array}{l}43.5 \\
\pm 5.1\end{array}$ & $\begin{array}{l}47.6 \\
\pm 3.1\end{array}$ & $\begin{array}{c}45.4 \\
\pm 3 \\
\end{array}$ & $\begin{array}{l}47.4 \\
\pm 2.7 \\
\end{array}$ & $\begin{array}{l}45.7 \\
\pm 2.3 \\
\end{array}$ & $\begin{array}{l}47.8 \\
\pm 4.1\end{array}$ & $\begin{array}{l}47.4 \\
\pm 3.4\end{array}$ & $\begin{array}{l}46.9 \\
\pm 2.5\end{array}$ & $\begin{array}{l}45.1 \\
\pm 8.2\end{array}$ & $\begin{array}{l}47.3^{\mathrm{a}} \\
\pm 3.2^{2}\end{array}$ & $\begin{array}{l}51.6^{\mathrm{b}} \\
\pm 2.2\end{array}$ & $\begin{array}{l}50.6^{\mathrm{b}} \\
\pm 4.9^{2}\end{array}$ \\
\hline $\begin{array}{l}\text { Number of } \\
\text { Kernels/row }\end{array}$ & $\begin{array}{l}20.9 \\
\pm 6.3\end{array}$ & $\begin{array}{l}24.2 \\
\pm 5.1\end{array}$ & $\begin{array}{r}23.5 \\
\pm 5.8\end{array}$ & $\begin{array}{r}26.6 \\
\pm 5.7\end{array}$ & $\begin{array}{l}21.4 \\
\pm 6.6\end{array}$ & $\begin{array}{l}27.1 \\
\pm 7.3\end{array}$ & $\begin{array}{r}25.6 \\
\pm 5.6\end{array}$ & $\begin{array}{l}26.8 \\
\pm 3.9\end{array}$ & $\begin{array}{r}27.2 \\
\pm 5.3\end{array}$ & $\begin{array}{l}24.1 \\
\pm 6.1\end{array}$ & $\begin{array}{l}25.8 \\
\pm 9.5\end{array}$ & $\begin{array}{l}25.5 \\
\pm 6.3\end{array}$ \\
\hline Number of rows/ear & $\begin{array}{l}15.5 \\
\pm 4.5\end{array}$ & $\begin{array}{l}16.0 \\
\pm 2.1\end{array}$ & $\begin{array}{r}14.3 \\
\pm 2.1\end{array}$ & $\begin{array}{l}15.3 \\
\pm 1.2\end{array}$ & $\begin{array}{l}14.9 \\
\pm 1.9\end{array}$ & $\begin{array}{c}15.4 \\
\pm 2.3\end{array}$ & $\begin{array}{r}16.7 \\
\pm 2.2\end{array}$ & $\begin{array}{r}17.7 \\
\pm 1.8\end{array}$ & $\begin{array}{r}16.6 \\
\pm 2.4\end{array}$ & $\begin{array}{r}14.9 \\
\pm 1.9\end{array}$ & $\begin{array}{c}16.3 \\
\pm 2\end{array}$ & $\begin{array}{r}15.5 \\
\pm 2.1\end{array}$ \\
\hline $\begin{array}{l}\text { Number of } \\
\text { kernels/ear }\end{array}$ & $\begin{array}{c}339.1 \\
\pm \\
197.6\end{array}$ & $\begin{array}{c}386 \\
\pm 89.2\end{array}$ & $\begin{aligned} & 340 \\
\pm & 105.4\end{aligned}$ & $\begin{array}{r}404.8 \\
\pm 84.1\end{array}$ & $\begin{array}{c}317.7 \\
\pm 98\end{array}$ & $\begin{array}{c}419.6 \\
\pm 139.7\end{array}$ & $\begin{array}{c}433.1 \\
\pm 132 \\
6\end{array}$ & $\begin{array}{c}480.4 \\
\pm 113 \\
4\end{array}$ & $\begin{array}{c}453.5 \\
\pm 112.6\end{array}$ & $\begin{array}{c}363.9 \\
\pm 113.6\end{array}$ & $\begin{array}{c}428.6 \\
\pm 167.4\end{array}$ & $\begin{array}{c}397.9 \\
\pm 116.1\end{array}$ \\
\hline
\end{tabular}

( \pm Indicates standard deviations of the means. Presence of different letters $a, b, c$ in the same line means that there is significant difference between the three treatments within the same cultivar at $\alpha=5 \%$. Numbers without letters means there is no significant difference. F1 treatment $=40$ tons $/$ Ha of horse-dung $+200 \mathrm{~kg} / \mathrm{Ha}$ of $15 \mathrm{~N}-15 \mathrm{P}-15 \mathrm{~K}$. F2 treatment $=30 \mathrm{tons} / \mathrm{Ha}$ of horse-dung $+150 \mathrm{~kg} / \mathrm{Ha}$ of $15 \mathrm{~N}-15 \mathrm{P}-$ $15 \mathrm{~K} . \mathrm{F} 3$ treatment $=50$ tons $/$ Ha of horse-dung $+250 \mathrm{~kg} / \mathrm{Ha}$ of $15 \mathrm{~N}-15 \mathrm{P}-15 \mathrm{~K}$.

\section{Biochemical characteristics of sweet corn ears grown at Sangalkam}

Table 4 shows data obtained for moisture content, reducing sugars, totals sugars and starch for four sweet corn cultivars grown at Sangalkam under three different fertilization treatments. All data were expressed in g. $100 \mathrm{~g}^{-1}$ fresh matter. For Excellis Garrison, water content $(79.4 \pm 1.1$ g. $100 \mathrm{~g}^{-1}$ ) from ears in treatment $\mathrm{F} 1$ was higher, followed by ears in treatments F3 and F2. Reducing sugar contents were similar for treatments F1 and F2 (2.9 g. $\left.100 \mathrm{~g}^{-1}\right)$ and higher for treatment F3 $\left(4.4 \pm 0.2 \mathrm{~g} .100 \mathrm{~g}^{-1}\right)$. Total sugar contents were significantly different $(\mathrm{p}<0.05)$ between $\mathrm{F} 1, \mathrm{~F} 2$ and F3 treatments with higher values in treatment F3 $\left(8.6 \pm 0.7 \mathrm{~g} .100 \mathrm{~g}^{-1}\right)$ followed by treatment F2 $\left(6.7 \pm 0.5\right.$ g. $\left.100 \mathrm{~g}^{-1}\right)$ and treatment F1 $(4.9 \pm 0.2$

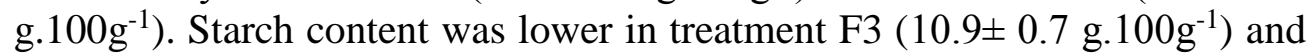

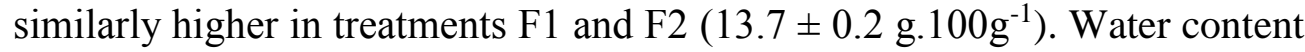
was the same in treatments F2 and F3, and higher in treatment F1 with 80.7 \pm 1.2 g. $100 \mathrm{~g}^{-1}$ for Legacy cultivar. Reducing sugar contents were higher in treatment F2, with an amount of $5.3 \pm 0.8 \mathrm{~g} .100 \mathrm{~g}^{-1}$, compared to treatments $\mathrm{F} 1$ and F3. Total sugar contents were the same in treatments F1 and F3 and lower in treatment F2 $\left(4.8 \pm 0.6\right.$ g. $\left.100 \mathrm{~g}^{-1}\right)$. Starch content ranged from 12.1 to 14.4 with the highest value in treatment F3. Fertilizer treatments did not have effects on water $\left(76.5 \pm 1.1\right.$ g. $\left.100 \mathrm{~g}^{-1}\right)$ and starch $\left(13.4 \pm 0.4 \mathrm{~g} .100 \mathrm{~g}^{-1}\right)$ contents of Infinity cultivar. Reducing sugars were similar in treatments F2 and F3 $\left(3.7 \pm 0.2\right.$ g. $\left.100 \mathrm{~g}^{-1}\right)$ and lower in treatment F1 $\left(2.5 \pm 0.3 \mathrm{~g} .100 \mathrm{~g}^{-1}\right)$. Total sugar contents were significantly different $(\mathrm{p}<0.05)$ in treatments $\mathrm{F} 1$, F2 and F3 with highest values in treatment F3 $(7.3 \pm 0.3)$, followed by F2

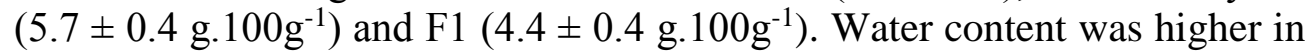
treatments F2 and F3 (around 80 g. $\left.100 \mathrm{~g}^{-1}\right)$ compared to treatment F1 (78.7 \pm 0.9 ) for Yosemite cultivar. Reducing sugar contents were the same in

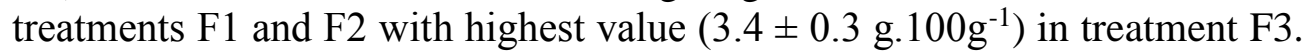
Total sugars were higher in treatment F1 $\left(8 \pm 0.5 \mathrm{~g}^{\left.-100 \mathrm{~g}^{-1}\right)}\right.$ than those recorded for treatments F2 $\left(6.9 \pm 0.4\right.$ g. $\left.^{100 g^{-1}}\right)$ and F3 $\left(6.3 \pm 0.8\right.$ g. $\left.100 \mathrm{~g}^{-1}\right)$. Starch content was higher in treatments F1 and F2 $\left(13.2 \pm 0.6\right.$ g. $\left.^{100 g^{-1}}\right)$ compared to treatment F3 $\left(11.6 \pm 0.4 \mathrm{~g}^{1} 100 \mathrm{~g}^{-1}\right)$. Water contents for Yosemite 
cultivar were slightly higher than those reported by Szymanek (2012) for Candle sh2 variety (76.4\%). For Excellis Garrison, Infinity and Legacy cultivars, moisture contents were closed to those recorded for Crisp-N-Sweet $710(75.9 \%)$, FMX (76.4\%) or Summer sweet 7210 (76.9\%) varieties (Wong et al., 1994). About total sugars and starch contents, our results were higher than those reported by Szymanek (2012) for Candle sh2 variety $(3.6 \%$ and $2.73 \%$ respectively for total sugars and starch). Differences could be from variations in harvest date or conditions of cultivation.

Table 4: Water, reducing sugars, total sugars and starch contents of sweet corn ears grown at Sangalkam

\begin{tabular}{|c|c|c|c|c|c|c|c|c|c|c|c|c|}
\hline & \multirow{2}{*}{\multicolumn{3}{|c|}{$\begin{array}{c}\text { Excellis Garrison } \\
\text { Treatments }\end{array}$}} & \multirow{2}{*}{\multicolumn{3}{|c|}{$\frac{\text { Legacy }}{\text { Treatments }}$}} & \multicolumn{3}{|c|}{ Infinity } & \multicolumn{3}{|c|}{ Yosemite } \\
\hline & & & & & & & & eatme & & & eatmen & \\
\hline & F1 & F2 & F3 & F1 & F2 & F3 & F1 & F2 & F3 & F1 & F2 & F3 \\
\hline Water content $\left(\mathrm{g} .100 \mathrm{~g}^{-1}\right)$ & $\begin{array}{l}79.4^{\mathrm{a}} \\
\pm 1.1\end{array}$ & $\begin{array}{l}75.03^{\mathrm{b}} \\
\pm 1.04\end{array}$ & $\begin{array}{l}76^{\mathrm{c}} \\
\pm 1.4\end{array}$ & $\begin{array}{l}80.7^{\mathrm{a}} \\
\pm 1.2\end{array}$ & $\begin{array}{c}76^{b} \pm \\
0.6\end{array}$ & $\begin{array}{l}77.6^{\mathrm{b}} \\
\pm 0.9\end{array}$ & $\begin{array}{r}77.1 \\
\pm 1.4\end{array}$ & $\begin{array}{r}75.8 \\
\pm 0.7\end{array}$ & $\begin{array}{l}76.6 \\
\pm 1\end{array}$ & $\begin{array}{l}78.7^{\mathrm{a}} \\
\pm 0.9\end{array}$ & $\begin{array}{l}80.6^{\mathrm{b}} \\
\pm 0.9\end{array}$ & $\begin{array}{l}80.3^{\mathrm{b}} \\
\pm 0.2\end{array}$ \\
\hline Reducing sugars $\left(\mathrm{g.100g}^{-1}\right)$ & $\begin{array}{l}2.9^{\mathrm{a}} \\
\pm 0.6\end{array}$ & $\begin{array}{c}2.8^{\mathrm{a}} \pm \\
0.6\end{array}$ & $\begin{array}{l}4.4^{\mathrm{b}} \\
\pm 0.2\end{array}$ & $\begin{array}{r}2.1^{\mathrm{a}} \\
\pm 0.6 \\
\end{array}$ & $\begin{array}{l}5.3^{\mathrm{b}} \\
\pm 0.8 \\
\end{array}$ & $\begin{array}{l}6.7^{\mathrm{a}} \\
\pm 0.3 \\
\end{array}$ & $\begin{array}{r}2.5^{\mathrm{a}} \\
\pm 0.3 \\
\end{array}$ & $\begin{array}{r}3.7^{\mathrm{b}} \\
\pm 0.2 \\
\end{array}$ & $\begin{array}{l}3.7^{\mathrm{b}} \\
\pm 0.4\end{array}$ & $\begin{array}{l}2.3^{\mathrm{a}} \\
\pm 0.2 \\
\end{array}$ & $\begin{array}{l}2.6^{\mathrm{a}} \\
\pm 0.6 \\
\end{array}$ & $\begin{array}{l}3.4^{\mathrm{b}} \\
\pm 0.3 \\
\end{array}$ \\
\hline Total sugars $\left(\mathrm{g.100g}^{-1}\right)$ & $\begin{array}{l}4.9^{\mathrm{a}} \\
\pm 0.2 \\
\end{array}$ & $\begin{array}{r}6.7^{\mathrm{b}} \\
\pm 0.5 \\
\end{array}$ & $\begin{array}{l}8.6^{\mathrm{c}} \\
\pm 0.7 \\
\end{array}$ & $\begin{array}{r}6.2^{\mathrm{a}} \\
\pm 0.7 \\
\end{array}$ & $\begin{aligned} & 4.8^{\mathrm{b}} \\
& \pm 0.6 \\
&\end{aligned}$ & $\begin{array}{c}6^{\mathrm{a}} \\
\pm 0.5 \\
\end{array}$ & $\begin{array}{r}4.4^{\mathrm{a}} \\
\pm 0.4 \\
\end{array}$ & $\begin{array}{l}5.7^{\mathrm{b}} \\
\pm 0.4 \\
\end{array}$ & $\begin{array}{r}7.3^{\mathrm{c}} \\
\pm 0.3 \\
\end{array}$ & $\begin{array}{r}8^{\mathrm{a}} \\
\pm 0.5 \\
\end{array}$ & $\begin{array}{r}6.9^{\mathrm{b}} \\
\pm 0.4 \\
\end{array}$ & $\begin{array}{r}6.3^{\mathrm{b}} \\
\pm 0.8 \\
\end{array}$ \\
\hline Starch $\left(\mathrm{g.100g^{-1 }}\right)$ & $\begin{array}{l}13.7^{\mathrm{a}} \\
\pm 0.2^{2}\end{array}$ & $\begin{array}{l}13.7^{\mathrm{a}} \\
\pm 0.2^{2}\end{array}$ & $\begin{array}{l}10.9^{\mathrm{b}} \\
\pm 0.7\end{array}$ & $\begin{array}{l}12.1^{\mathrm{a}} \\
\pm 1.3\end{array}$ & $\begin{array}{l}12.3^{\mathrm{a}} \\
\pm 0.9\end{array}$ & $\begin{array}{l}14.4^{\mathrm{b}} \\
\pm 0.5\end{array}$ & $\begin{array}{r}13.2 \\
\pm 0.5\end{array}$ & $\begin{array}{c}13.8 \\
\pm 0.3\end{array}$ & $\begin{array}{c}13.1 \\
\pm 0.04\end{array}$ & $\begin{array}{l}13.2^{\mathrm{a}} \\
\pm 0.6\end{array}$ & $\begin{array}{l}13.1^{\mathrm{a}} \\
\pm 0.4\end{array}$ & $\begin{array}{l}11.6^{\mathrm{b}} \\
\pm 0.4\end{array}$ \\
\hline $\begin{array}{l}\text { ( } \pm \text { Indicates standard deviat } \\
\text { between the three treatment } \\
\text { treatment }=40 \text { tons } / \text { Ha of ho }\end{array}$ & s of the & neans. & sence & & & & & & & & & \\
\hline
\end{tabular}

\section{Biochemical characteristics of sweet corn ears grown at Ndiol}

Table 5 shows data recorded on water content, reducing sugars, totals sugars and starch contents for the four sweet corn cultivars grown at Ndiol under three different fertilization treatments. For Excellis Garrisson, there were no significant differences between treatments F1, F2 and F3 for water content, reducing sugars, total sugars and starch. For Legacy, water content was the same for treatments F1 and F3 and slightly lower in F2. Reducing sugars were higher in treatments F2 and F3 than in F1. Total sugars were lower in F2 than in treatments F1 and F3. Significant differences $(p<0.05)$ were noticed between treatments F1, F2 and F3 on starch content with the highest in F1 treatment. Considering Infinity cultivar, water content and total sugars were the same in treatments F1, F2 and F3. Reducing sugars were higher in F3 treatment while starch contents were higher in treatments F2 and F3. Yosemite showed ears with higher total sugar content in treatment F1 and high starch content in treatment F2. Fertilizer treatments did not affect reducing sugar contents. Total sugar contents were significantly different $(\mathrm{p}<0.05)$ in treatments $\mathrm{F} 1, \mathrm{~F} 2$ and F3 with highest values in treatment F3 $(7.3 \pm 0.3)$. 
Table 5: Water, reducing sugars, total sugars and starch contents of sweet corn ears grown at Ndiol

\begin{tabular}{|c|c|c|c|c|c|c|c|c|c|c|c|c|}
\hline & \multicolumn{3}{|c|}{$\begin{array}{c}\text { Excellis Garrison } \\
\text { Treatments }\end{array}$} & \multicolumn{3}{|c|}{$\begin{array}{c}\text { Legacy } \\
\text { Treatments }\end{array}$} & \multicolumn{3}{|c|}{$\begin{array}{c}\text { Infinity } \\
\text { Treatments } \\
\end{array}$} & \multicolumn{3}{|c|}{$\begin{array}{l}\text { Yosemite } \\
\text { Treatments }\end{array}$} \\
\hline & F1 & F2 & F3 & F1 & F2 & F3 & F1 & F2 & F3 & F1 & F2 & F3 \\
\hline $\begin{array}{l}\text { Water content (g.100g- } \\
1)\end{array}$ & $\begin{array}{l}78.9 \\
\pm 0.6\end{array}$ & $\begin{array}{l}78.9 \\
\pm 0.6\end{array}$ & $\begin{array}{l}78.9 \\
\pm 0.7\end{array}$ & $\begin{array}{l}77.6^{\mathrm{a}} \\
\pm 0.8\end{array}$ & $\begin{array}{c}76^{\mathrm{b}} \\
\pm \\
0.8\end{array}$ & $\begin{array}{l}77.8^{\mathrm{a}} \\
\pm 0.5\end{array}$ & $\begin{array}{l}77.9 \\
\pm 0.7\end{array}$ & $\begin{array}{l}78.6 \\
\pm 0.6\end{array}$ & $\begin{array}{r}78.9 \\
\pm 0.8\end{array}$ & $\begin{array}{l}78.7^{\mathrm{a}} \\
\pm 0.8\end{array}$ & $\begin{array}{c}77.4 \\
\mathrm{ab} \pm \\
0.9\end{array}$ & $\begin{array}{c}75.6^{\mathrm{b}} \pm \\
1.5^{5}\end{array}$ \\
\hline $\begin{array}{l}\text { Reducing sugars } \\
\quad\left(\mathrm{g} .100 \mathrm{~g}^{-1}\right)\end{array}$ & $\begin{array}{c}3.4 \\
\pm 0.2\end{array}$ & $\begin{array}{l}3.5 \pm \\
0.6\end{array}$ & $\begin{array}{c}3.8 \\
\pm 0.7\end{array}$ & $\begin{array}{r}3.7^{b} \\
\pm 0.5\end{array}$ & $\begin{array}{c}4.6^{\mathrm{a}} \\
\pm \\
0.3 \\
\end{array}$ & $\begin{array}{l}5.2^{\mathrm{a}} \\
\pm 0.3\end{array}$ & $\begin{array}{l}4.6^{\mathrm{a}} \\
\pm 0.3\end{array}$ & $\begin{array}{l}3.7^{\mathrm{a}} \\
\pm 1\end{array}$ & $\begin{array}{l}5.8^{b} \\
\pm 0.6\end{array}$ & $\begin{array}{c}5.7 \\
\pm 1.3\end{array}$ & $\begin{array}{c}4.9 \\
\pm 0.6\end{array}$ & $\begin{array}{c}5.4 \\
\pm 1.03\end{array}$ \\
\hline Total sugars $\left({\left.\mathrm{g} .100 \mathrm{~g}^{-1}\right)}^{-1}\right.$ & $\begin{array}{c}5.2 \\
\pm 0.5\end{array}$ & $\begin{array}{c}6.2 \\
\pm 0.7\end{array}$ & $\begin{array}{c}6.1 \\
\pm 0.7\end{array}$ & $\begin{array}{r}7.3^{\mathrm{a}} \\
\pm 0.1\end{array}$ & $\begin{array}{c}6^{\mathrm{b}} \\
\pm \\
0.6\end{array}$ & $\begin{array}{l}6.7^{\text {a }} \\
\pm 0.4\end{array}$ & $\begin{array}{c}5.7 \\
\pm 0.6\end{array}$ & $\begin{array}{c}6.2 \\
\pm 4.4\end{array}$ & $\begin{array}{c}5.7 \\
\pm 2.1\end{array}$ & $\begin{array}{r}7.8^{\mathrm{a}} \\
\pm 0.6\end{array}$ & $\begin{array}{c}6^{\mathrm{b}} \\
\pm 0.5\end{array}$ & $\begin{array}{r}6.4^{\mathrm{b}} \\
\pm 0.5\end{array}$ \\
\hline $\operatorname{Starch}\left(\mathrm{g} .100 \mathrm{~g}^{-1}\right)$ & $\begin{array}{r}11.7 \\
\pm 0.7\end{array}$ & $\begin{array}{r}11.9 \\
\pm 0.4\end{array}$ & $\begin{array}{r}11.3 \\
\pm 0.8\end{array}$ & $\begin{array}{c}11.2^{\mathrm{a}} \\
\pm \\
0.04\end{array}$ & $\begin{array}{c}10^{\mathrm{b}} \\
\pm \\
0.3\end{array}$ & $\begin{array}{l}9.4^{\mathrm{c}} \\
\pm 0.2^{2}\end{array}$ & $\begin{array}{l}11.1^{\mathrm{a}} \\
\pm 0.2^{2}\end{array}$ & $\begin{array}{l}12.2^{b} \\
\pm 0.2^{b}\end{array}$ & $\begin{array}{l}12.1^{\mathrm{b}} \\
\pm 0.3\end{array}$ & $\begin{array}{l}10.2^{\mathrm{a}} \\
\pm 0.2^{2}\end{array}$ & $\begin{array}{l}13.5^{b} \\
\pm 0.2\end{array}$ & $\begin{array}{c}11.04^{\mathrm{a}} \\
\pm 1\end{array}$ \\
\hline
\end{tabular}

( \pm ) Indicates standard deviations of the means. Presence of different letters $a, b, c$ in the same line means that there is significant difference between the three treatments within the same cultivar at $\alpha=5 \%$. Numbers without letters means there is no significant difference. F1 treatment $=40$ tons $/$ Ha of horse-dung $+200 \mathrm{~kg} / \mathrm{Ha}$ of $15 \mathrm{~N}-15 \mathrm{P}-15 \mathrm{~K} . \mathrm{F} 2 \mathrm{treatment}=$ 30 tons $/$ Ha of horse-dung $+150 \mathrm{~kg} / \mathrm{Ha}$ of $15 \mathrm{~N}-15 \mathrm{P}-15 \mathrm{~K} . \mathrm{F3}$ treatment $=50$ tons $/ \mathrm{Ha}$ of horse-dung $+250 \mathrm{~kg} / \mathrm{Ha}$ of $15 \mathrm{~N}-$ $15 P-15 K$.

\section{Conclusion}

The number of kernels/ear is one of the most important physical parameters for producing sweet corn suitable for canning. Among the four cultivars tested, F3 fertilization treatment (50 tons/Ha horse dung +250 $\mathrm{kg} / \mathrm{Ha}$ of $15 \mathrm{~N}-15 \mathrm{P}-15 \mathrm{~K}$ ) led to the highest number of kernels/ear. Yosemite cultivar showed the highest number of kernels/ear (672.3) followed respectively by Legacy (642), Excellis Garrison (585.6) and Infinity (573). Water and sugar contents, reported as the main attributes of the sweet corn quality for processing, also represent important parameters to be considered in selecting variety to avoid Mallard reaction and loss in kernel tenderness. Legacy cultivar exhibited, at the same time, the highest content of reducing sugars in treatment F1 and the lowest amount of reducing sugars in treatment F3. Also, Legacy cultivar presented the highest starch content in treatment F3. From these results, Yosemite and Legacy cultivars would be more suitable for sweet corn canning in Senegal. In this regard, Sangalkam could be reported as the best place for sweet corn production. Nevertheless, other studies need to be carried out over several years in order to assess the behavior of studied cultivars in longer terms for canning processing. It would be relevant to consider the edaphic characteristics, in particular by advanced physical and chemical analyses of the soil, for a better adaptation to amounts of fertilization. Further tests need to be conducted in order to collect data on post harvest storage and suitability for sweet corn production as well as canning processing. 


\section{Conflict of interest}

The authors have not declared any conflict of interests.

\section{Acknowledgments}

The authors are very thankful to SCL society for supplying of sweet corn cultivars seeds. Support for this research was provided by USAID Cooperative Agreement number 685-A-00-10-00194-00 from the US Agency for International Development. The authors would like to thank Ms. Fabrina DELSOIN for her contribution to experimental field essays.

\section{References:}

1. Alan, O., Kinaci, G., Kinaci, E., Budak Basciftci, Z., Sonmez, K., Evrenosoglu, Y., Kutlu, I. (2014). Kernel Quality of Some Sweet Corn Varieties in Relation to Processing. Not. Bot. Horti. Agrobo 42 (2):414-419.

2. AOAC (Association of Official Analytical Chemists). (1990). Fruits and Fruits Products. In: K. Helrich (Ed.), Official methods of analysis of the association of official analytical chemists (pp. 910-928). Arlington, USA7.

3. AOAC (Association of Official Analytical Chemists). (2007). Official Methods of Analysis of AOAC International, vol. 2, 18th éd.

4. Aprifel. (2012). White paper - Maïs Doux. 05 January 2012. $<$ http://www.aprifel.com>.

5. Azanza, F., Juvik, J.A., Klein, B.P. (1994). Relationships between sensory quality attributes and kernel chemical composition. J. Food Qual. 17:150-172.

6. Azanza, F., Bar-Zur, A., Juvik, J.A. (1996). Variation in Sweet Corn Kernel Characteristics Assiociated with Stand Establishment and Eating Quality. Euphytica 87:7-18.

7. Carey, E.E., Dickinson, D.B., Rhodes, A.M. (1982). Post-harvest Levels of Sugars and Sorbitol in Sugary Enhancer (su1se1) and Sugary (su1Se1) Maize. HortScience 17:241-242.

8. Carey, E.E., Dickinson, D.B., Rhodes, A.M. (1984). Sugar Characteristics of Sweet Corn Populations from a Sugary Enhancerbreeding Program. Euphytica 33:609-622.

9. Creech, R.G. (1965). Genetic Control of Carbohydrate Synthesis in Maize Endosperm. Genetics 52: 1175-1186.

10. Diallo, M.D., Toure, A., Diop Mbacké, F., Saleh, M.M., Touroumgaye, G., Ndiaye, A.B., Diop Ndiaye, N., Diop, A., Guissé, A. (2016.) Détermination de la Dose Optimale d'Engrais Minéral 1515-15 sur 5 Variétés de Maïs Doux (Zea mays L. ssp. Saccharata) au Sénégal. European Scientific Journal, 12 (27):165-148. 
11. Delsoin, F.L.T. (2014). Détermination de la Dose Optimale d'Engrais Minéral 15-15-15 sur Cinq Variétés de Maïs doux (Zea mays L. ssp saccharata). Université de Thiès, Sénégal, Diplôme d'Ingénieur des Travaux.

12. Direction de 1'Horticulture (DHORT). (2016). Annual Report for 2015; Ministère de 1'Agriculture et de 1' Equipement rural, DakarSénégal.

13. Evensen, K.B. and Boyer, C.D. (1986). Carbohydrate Composition of Sensory Quality of Fresh and Store Sweet Corn. J. Amer. Soc. Hort. Sci. 111: 734-738.

14. Flora, L.F. and Wiley, R.C. (1974). Sweet corn aroma, chemical components, and relative importance in the overall flavor response. $\mathrm{J}$. Food Sci. 39: 770-773.

15. Garwood, D.L., McArdle, F.J., Vanderslice, S.F., Shannon, J.C. (1976). Postharvest Carbohydrate Transformation and Processed Quality of High Sugar Maize Genotypes. J. Amer. Soc. Hort. Sci. 101: 400-404.

16. Hale, T.A., Hassell, R.L., Phillips, T., Halpin, E. (2005). Taste Panel Perception of Sweetness and Sweetness Acceptability Compared to High Pressure Liquid Chromatography Analysis of Sucrose and total Sugars among Three Phenotype (su, se, and sh2) at Varying Maturity of Sweet Corn. HortTechnology, 15 (2): 313-317.

17. Haris Morran Seed Company. (2013). Yosemite, Hybrid Shrunken-2 Sweet Corn with Great Yield Potential.

18. Mullins, C.A., Straw, R.A., Pitt, B. Jr., Onks, D.O., Mullen, M.D., Reynolds, J., Kirchner, M. (1999). Response of Selected Sweet Corn Cultivars to Nitrogen Fertilization. HortTechnology, 9(1): 32-35.

19. Lertrat K., Pulam, T. (2007). Breeding for Increased Sweetness in Sweet Corn. Int. J. Plant. Breed 1(1):27-30.

20. Péron, J.Y. (2006). Références Productions Légumières. Lavoisier, 2nde édition, 432-439.

21. Salunkhe, D.K., Kadam, S.S. (1998). Handbook of Vegetable Science and Technology: Production, Composition, Storage and Processing. Marcel Dekker, Inc.

22. Senegalese Agency for Foreign Commerce (SAFC). (2016). Annual Report for 2015; Ministère du Commerce, Dakar-Sénégal.

23. Showalter, R.K. and Miller, L.W. (1962). Consumer Preference for High Sugar Sweet Corn Varieties. Proc. Fla. State Hort. Soc. 75:278280.

24. Simonne, E., Simonne, A., Boozer, R. (1999). Yield, Ear Characteristics and Consumer Acceptance of White Sweet Corn 
Varieties in the Southeastern United States. HortTechnology, 9 (2): 289-293.

25. Sow, A., Lagnane, O. (2011). Culture maraîchère : maïs doux. Créneaux porteurs du secteur primaire. 05 January 2012. $<\mathrm{http} / /$ :www.dasp.gouv.sn>.

26. Starke Ayres. (2013a). Legacy, F1 Augmented Sweet Corn Hybrid.

27. Starke Ayres. (2013b). Infinity, New Supersweet Sweet Corn Variety for the Fresh Market.

28. Sy Diouf, A.A. (2013). Etude du marché des conserves de maïs doux au Sénégal. Université de Thiès, Ecole Nationale Supérieure d'Agriculture, Engineer Diss. 96p.

29. Syngenta Seeds S.A.S. (2013). Sweet Corn Garrison Technical Sheet.

30. Szymanek, M., Dobrzañski, Jr. B., Niedziólka, I., Rybczyñski, R. (2006). Sweet Corn: Harvest and Technology, Physical Properties and Quality. 1e ed. B. Dobrzański Institute of Agrophysics of Polish Academy of Sciences.

31. Szymanek, M. (2012). Processing of Sweet Corn. Trends in Vital Food and Control Engineering, Prof. Ayman Amer Eissa (Ed.), ISBN: 978-953-51-0449-0, InTech, Available from: http://www.intechopen.com/books/trends-in-vital-food-and-controlengineering/processing-of-sweet-corn

32. Warzecha, R. (2003). Słodki smak kukurydzy. Owoce warzywa kwiaty, Vol. 6, 20-21.

33. Wong A.D., Juvik, J.A., Breeden, D.C., Swiader, J.M. (1994). Shrunken 2 Sweet Corn Yield and the Chemical Components of Quality. J. Amer. Hort. Sci, 119(4):747-755. 